\title{
Calibration of Digital Cameras for Mobile Mapping Purposes
}

\author{
Parningotan Hasudungan Situmorang ${ }^{1}$, Catur Aries Rokhmana ${ }^{2}$ \\ 1 Mahasiswa Magister Teknik Geomatika UGM, Departemen Teknik Geodesi FT-UGM \\ 2 Staf Pengajar, Departemen Teknik Geodesi FT-UGM
}

\section{Article History:}

Received 12 November 2018

Received in revised form 5 June 2019

Accepted 11 June 2019

Available online 28 June 2019

\section{Keywords:}

Kalibrasi, test field calibration, IOP, mobile mapping

\section{Corresponding Author:}

Parningotan Hasudungan Situmorang

Email: parningotan.h@mail.ugm.ac.id

\begin{abstract}
The development of the use of non-metric digital cameras in the form of action cameras for collecting geospatial data has become very useful and supports the work of mobile mapping for making three-dimensional (3D) models. Each lens has an error in the formation of a projection design and also an error during production. For example in a fisheye lens, which has a distortion model, namely radial distortion, tangential distortion, and shifting of the optical center point. The camera is considered to be calibrated if the principal distance, principal point offset, and lens distortion parameters are known. The preparation stage that needs to be done on the mobile mapping work in making $3 D$ models is camera calibration. This research aims to determine the value of internal orientation parameters of a digital camera (action camera) that is used for mobile mapping purposes. Camera calibration in Photogrammetry aims to determine the geometric model of the camera described by Interior Orientation Parameters (IOP), including focal length, shifting principle point (PP), distortion, and other parameters. The calibration method used is the test field calibration. The calibration activities carried out on digital cameras are by measuring targets in the field using coded targets from Agisoft software. The calibration process is also carried out when processing photo data with Agisoft Photoscan Professional software. Camera calibration results using bundle adjustment on Agisoft Photoscan Professional software produce IOP (Interior Orientation Parameter) parameters, namely principal distance $(C)$, principal point $\left(x_{0}, y_{0}\right)$, and lens distortion parameters $\left(K_{1}, K_{2}, K_{3}, P_{1}, P_{2}, B_{1}, B_{2}\right)$. Based on the results obtained, it can be concluded that Maximum Observational Radial Distance Encountered is $1 \mathrm{~mm}$.
\end{abstract}

(C) Author(s) 2019. This is an open access article under the Creative Commons Attribution-ShareAlike 4.0 International License (CC BY-SA 4.0).

\section{Pendahuluan}

Teknologi mobile mapping merupakan teknologi pemetaan dengan wahana yang bergerak yang dilengkapi dengan multi sensor seperti sensor kamera digital, sensor Global Navigation Satellite System (GNSS), sensor Inertial Measurement Unit (IMU), sensor laser scanner, dan perangkat penyimpanan data. Keseluruhan komponen sensor tersebut terintegrasi pada wahana yang bergerak (mobil, sepeda motor, manusia, van, kereta api, perahu, dan sebagainya). Pembuatan model tiga dimensi (3D) dapat dilakukan dengan teknologi mobile mapping berupa Mobile Mapping System (MMS) dengan teknik Close Range Photogrammetry (CRP).

Berdasarkan karakteristik kamera digital, penggunaannya mulai meluas untuk kegiatan pengumpulan data dengan Unmanned Aerial Vehicle (UAV), MMS, maupun kegiatan Fotogrametri lainnya (Teo, 2015). Pada MMS terdapat beberapa jenis kamera yang umumnya digunakan, yaitu industrial (industri), Digital Single Lens Reflex (DSLR), Mirrorless Compact System, medium format (format sedang) (Cox, 2016). Kamera digital non-metrik digunakan untuk menggantikan kamera digital metrik, karena dapat mengurangi biaya dalam pengumpulan data foto obyek dunia nyata (real world) dengan teknik CRP.

Perkembangan penggunaan kamera digital non-metrik berupa action camera untuk pengumpulan data geospasial menjadi sangat bermanfaat dan mendukung pekerjaan mobile mapping untuk pembuatan model 3D. Namun kekurangan kamera digital non-metrik yaitu kualitas geometriknya yang kurang baik, yang mengakibatkan posisi pada foto yang dihasilkan kurang akurat. Sehingga diperlukan kalibrasi kamera untuk tahap persiapan pada pekerjaan mobile mapping dalam pembuatan model 3D. Pada kamera non metrik dapat dilakukan kalibrasi untuk menghilangkan kesalahan sistematik dan mendapatkan hasil yang baik untuk aplikasi terapan Fotogrametri terestris (Wolf et al., 2014). 
Menurut (Remondino \& Fraser, 2006), kamera dianggap sudah terkalibrasi jika principal distance, principal point offset, dan parameter distorsi lensa sudah diketahui. Setiap lensa memiliki kesalahan dalam pembentukan desain proyeksi dan juga kesalahan saat produksi. Sebagai contoh pada lensa fisheye, yang memiliki model distorsi, yaitu distorsi radial, distorsi tangensial, dan pergeseran titik pusat optik. Proyeksi lensa fisheye direpresentasikan sebagai fungsi linier, sinus, atau tangen dari sudut datang $(\theta)$ (Wolf et al., 2014).

Berdasarkan hasil penilaian kalibrasi kamera yang dilakukan oleh Hassan, jumlah piksel berbanding terbalik dengan keakuratan kamera. Karena jumlah foto berkurang, pengaturan ditetapkan sebagai default dan penggunaan prosedur standar, semakin tinggi dan dioptimalkan keakuratan kalibrasi kamera karena memiliki RMSE yang lebih kecil. Selain itu, metode standar yang dikembangkan oleh Eos Systems Inc. dalam hal pengaturan dan prosedur gambar memiliki RMSE yang lebih kecil. Compact camera tidak konsisten dalam hal distorsi lensa (Hassan et al., 2014).

Penelitian ini bertujuan untuk mengetahui nilai parameter orientasi internal dari kamera digital (action camera) yang digunakan untuk keperluan mobile mapping. Kalibrasi kamera dalam Fotogrametri bertujuan untuk menentukan model geometrik kamera yang dijelaskan oleh Interior Orientation Parameter (IOP), termasuk panjang fokus, pergeseran principle point (PP), distorsi, dan parameter lainnya.

\section{Data dan Metodologi}

Kegiatan kalibrasi yang dilakukan pada kamera digital yaitu dengan mengukur target yang ada di lapangan menggunakan coded targets dari perangkat lunak Agisoft Photoscan Profesional. Proses kalibrasi juga dilakukan pada saat pengolahan data foto dengan perangkat lunak Agisoft Photoscan Profesional.

\subsection{Data dan Lokasi}

Penelitian ini dilakukan di dalam ruangan (indoor) yaitu pada objek bagian dalam fasad bangunan rumah. Peralatan yang digunakan dalam penelitian ini adalah Personal Computer (PC), kamera digital non-metrik (action camera), coded targets, jalon (mounting camera), meteran baja, perangkat lunak Agisoft Photoscan Professional, dan Microsoft Office. Bahan penelitian yang digunakan adalah data hasil pemotretan objek bagian dalam fasad bangunan rumah, yang berupa data foto yang terdapat coded targets. Data hasil pengukuran jarak langsung antara dua buah coded targets yang telah dipasang pada objek yang difoto di lapangan dijadikan sebagai analisis perbandingan jarak (scale bar coded targets).

\subsection{Metodologi}

Menurut Tang (2013), kalibrasi kamera pada Fotogrametri merupakan suatu penentuan kegiatan dan proses tertentu pengukuran spesifik pada kamera, instrumen, perangkat lain yang dibandingkan dengan standar tertentu yang kemudian digunakan untuk memperbaiki atau mengatasi kesalahan saat perekaman data. Kalibrasi kamera dapat menentukan model geometrik kamera yang dijelaskan dengan diperolehnya Interior Orientation Parameter (IOP). Menurut (Clarke \& Fryer, 1998; Kraus, 1997; Luhmann et al., 2006; McGlone et al., 2004) yang dirangkum dalam disertasi Tang (2013), beberapa teknik kalibrasi yang telah digunakan dalam Fotogrametri adalah sebagai berikut :

1. Teknik laboratory calibration, yaitu teknik kalibrasi yang sering digunakan untuk kamera metrik. Parameter Interior Orientation (IO) ditentukan dengan Goniometer, Collimators atau instrument optikal lainnya.

2. Teknik test field calibration, dilakukan dengan mengukur target yang ada di lapangan yang telah diketahui koordinatnya dengan bidang uji yang direkam dari stasiun pengamatan multi-view. Kalibrasi ini diproses dengan Bundle Adjustment untuk menghitung IOP.

3. Teknik kalibrasi plumb-line, garis lurus harus dicitrakan sebagai garis lurus dan semua penyimpangan disebabkan adanya distorsi.

4. Kalibrasi in-situ, teknik ini juga dikenal sebagai on the job calibration yang menunjukkan bidang uji kalibrasi dengan kombinasi koordinat yang diketahui dari pengukuran objek sebenarnya.

5. Self-calibration, teknik ini dipertimbangkan sebagai proses lanjutan teknik test field calibration dan kalibrasi in-situ.

Pada penelitian ini, untuk menghasilkan parameter orientasi dalam, dilakukan implementasi kalibrasi kamera pada pengolahan data foto objek fasad bangunan bagian dalam rumah, yang sudah terpasang 14 buah coded targets. Pemotretan objek menghasilkan 20 buah foto beserta coded targets, yang diolah secara Fotogrametri (Bundle Adjustment) sampai menghasilkan model 3D objek fasad bangunan. Adapun diagram alir penelitian ini, dapat dilihat pada Gambar 2.1.

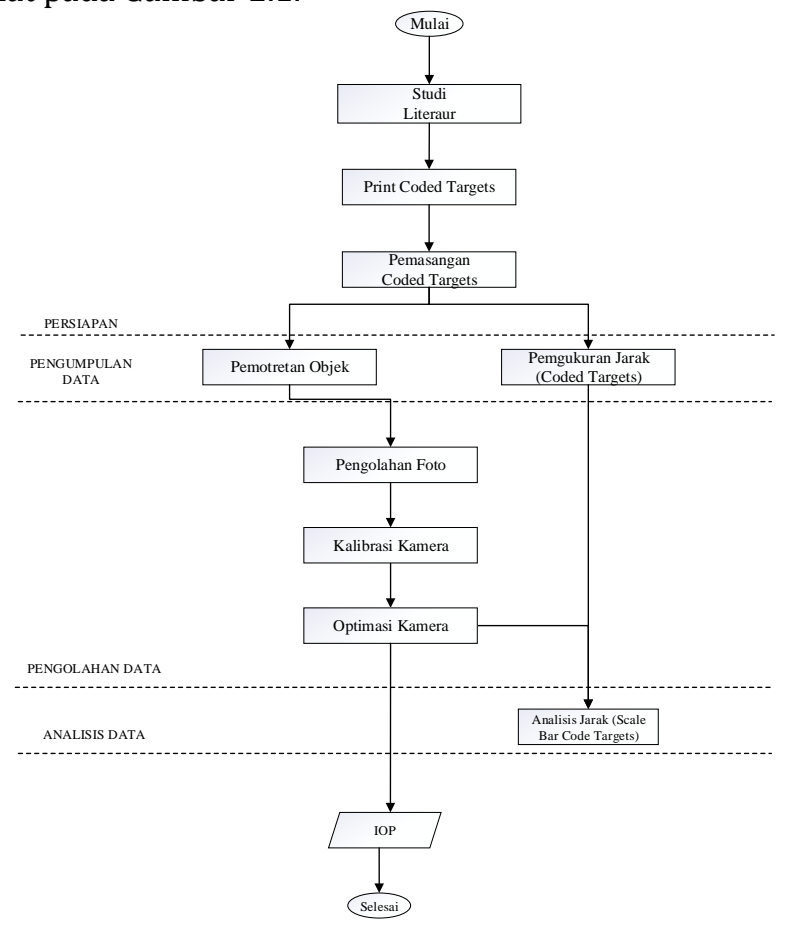

Gambar 2.1 Diagram Alir Penelitian 


\subsection{Coded Targets}

Coded targets adalah penanda yang dicetak untuk ditempatkan pada objek yang akan difoto, dan dapat digunakan dalam software Agisoft Photoscan Professional sebagai titik referensi untuk sistem koordinat. Coded targets digunakan untuk mempercepat proses pengolahan foto pada tahap Align Photos pada software Agisoft Photoscan Professional. Penggunaan coded targets ini juga dapat membantu kalibrasi kamera otomatis yang secara akurat menentukan foto yang saling bersesuaian.

Pada penelitian ini, coded target dicetak menggunakan marker type 12 bit, sebanyak 14 coded targets. Pemasangan coded targets pada objek (scene) yang akan difoto harus datar dan terhindar dari perubahan bentuk (pergeseran tempat). Coded targets berbentuk lingkaran dengan segmen hitam dan putih. Pada Gambar 2.2, dapat dilihat coded targets yang digunakan dalam penelitian ini dengan pola yang berbeda-beda.

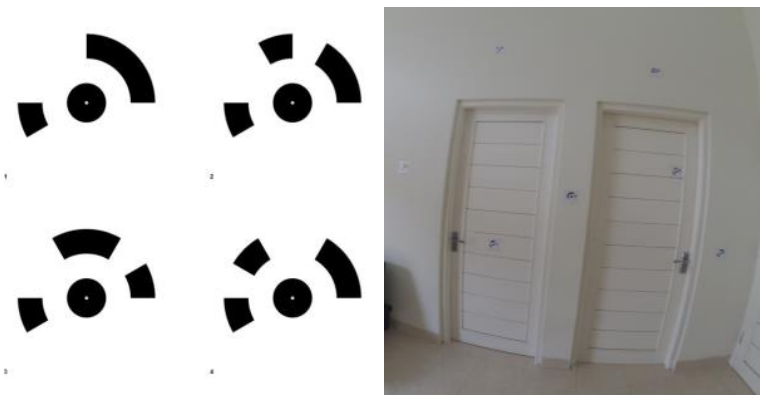

Gambar 2.2 Coded Targets 12 bit dan pemasangan pada objek

\subsection{Pengumpulan Data}

Pengumpulan data yang dilakukan yaitu pemotretan objek yang sudah terpasang coded targets dan pengukuran jarak antara dua buah coded targets. Teknik pengambilan foto dilakukan dengan teknik mobile mapping, yang menghasilkan 20 gambar/foto dengan 20 camera stations. Kamera dipasang pada ujung atas jalon dengan mode kamera landscape, yang dibawa oleh manusia berjalan sepanjang koridor objek yang difoto. Posisi kamera selama proses akuisisi foto dapat dilihat pada Gambar 2.3.

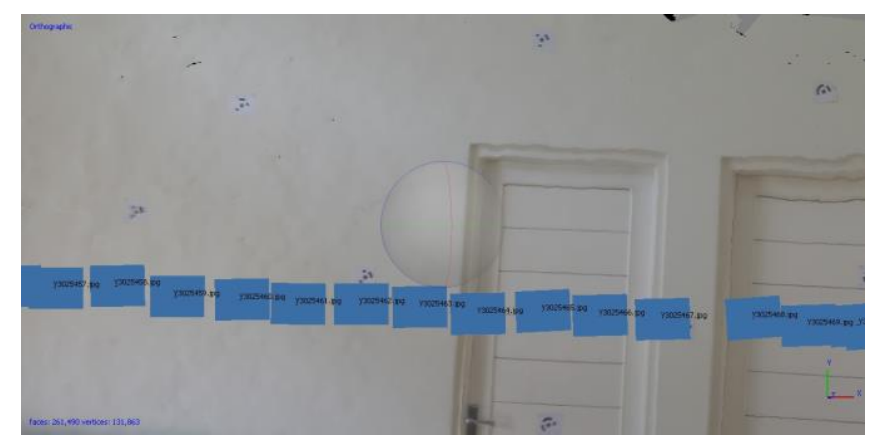

Gambar 2.3 Posisi camera station

Pengukuran jarak langsung di lapangan (objek) antara dua buah coded targets dilakukan untuk memperoleh data jarak/panjang antara dua buah coded targets. Pengukuran jarak langsung menggunakan meterean baja, dilakukan untuk keperluan analisis jarak scale bars setiap pasangan coded targets. Pasangan coded targets yang diukur jaraknya di lapangan (objek) ditampilkan dalam Tabel 2.1 dan Gambar 2.4.

Tabel 2.1 Pengukuran jarak antara dua buah coded targets pada objek yang difoto di lapangan

\begin{tabular}{cc}
\hline Label Coded Targets & Distance (m) \\
\hline Target 17 - Target 19 & 1,082 \\
Target 17 - Target 18 & 0,924 \\
Target 18 - Target 19 & 0,661 \\
Target 15 - Target 19 & 2,520 \\
Target 15 - Target 18 & 2,205 \\
Target 15 - Target 17 & 1,441 \\
Target 17 - Target 34 & 2,676 \\
Target 15 - Target 34 & 1,247 \\
\hline
\end{tabular}

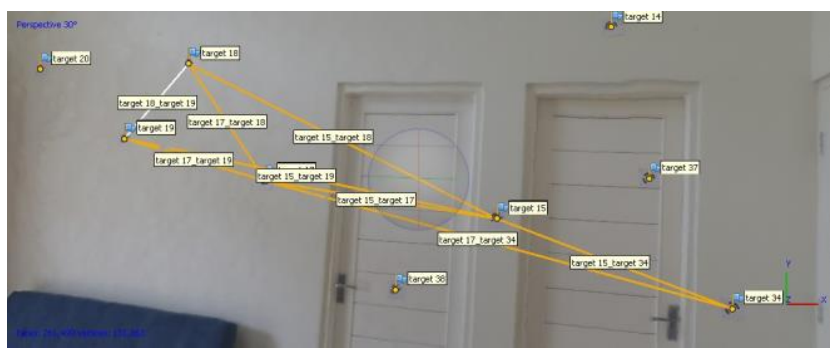

Gambar 2.4 Pengukuran jarak antara dua buah coded targets pada objek yang difoto di lapangan

\subsection{Pengolahan Foto}

Pengolahan data foto ini dilakukan dengan pembuatan stereo foto yang meliputi proses alignment photo (image matching), proses gradual selection, dan pembuatan dense cloud. Gradual selection merupakan proses untuk menghilangkan point cloud yang memiliki tingkat ketidaksesuaian atau error yang tinggi. Proses pembuatan dense cloud merupakan metode yang paling sesuai untuk pembuatan model 3D tekstur pada objek.

Tahapan selanjutnya yaitu pembuatan model 3D, dimana dense point cloud yang telah terbentuk dihubungkan satu sama lain membentuk jaring segitiga atau Triangular Irregular Network (TIN). Proses ini disebut sebagai proses pembuatan mesh atau model geometri dengan metode arbitrary. Metode arbitrary merupakan metode pembentukan geometri permukaan untuk berbagai macam objek yang diakuisisi dari jarak dekat, misalnya candi, bangunan, dan lain-lain (Agisoft, 2017). Pembentukan model 3D dilanjutkan ke tahap pemberian tekstur pada permukaan objek. Proses texturing ini bertujuan agar model 3D yang dihasilkan memiliki kenampakan yang mirip dengan kondisi di lapangan.

\subsection{Kalibrasi Kamera}

Metode kalibrasi yang digunakan yaitu test field calibration. Test field adalah salah satu bagian penting dari 
kalibrasi kamera. Test field dikembangkan sesuai dengan kebutuhan penelitian. Kamera dikalibrasi dengan metode test field terestris menggunakan Bundle Adjustment konvensional dengan model matematis kolinearitas yang dirancang khusus untuk lensa fisheye. Model matematis kolinearitas dikombinasikan dengan model distorsi lensa umumnya digunakan dalam proses kalibrasi kamera fotogrametrik.

Menurut penelitian yang pernah dilakukan oleh Hanifa, bahwa untuk keperluan geometrik yang cukup tinggi sudah seharusnya semua parameter internal kamera digunakan untuk meningkatkan ketelitian koordinat. Penentuan parameter internal kamera atau proses kalibrasi kamera harus dilakukan pada waktu yang sedekat mungkin dengan waktu pemanfaatan kamera tersebut atau idealnya kalibrasi dilakukan secara simultan dengan saat pemakaian kamera untuk aplikasi tertentu atau biasa disebut dengan metode self-calibration (Hanifa, 2007).

Pada saat pemotretan, berkas sinar dari objek merambat menyerupai garis lurus menuju pusat lensa kamera hingga berkas sinar ini mencapai bidang proyeksi. Kondisi dimana titik objek pada dunia nyata (real world), titik pusat proyeksi (pusat kamera), dan titik objek pada bidang foto terletak satu garis dalam suatu ruang dinamakan kondisi kesegarisan berkas sinar atau kondisi kolinieritas (collinearity condition). Kondisi ini merupakan syarat fundamental dalam Fotogrametri, dimana penyelesaian umum untuk setiap masalah dalam CRP dapat diperoleh dengan menerapkan persamaan kolinieritas. Pusat proyeksi digunakan pada saat perekaman, dimana garis-garis proyeksi dari objek dengan koordinat ruang $\mathrm{A}\left(X_{\mathrm{A}}, Y_{\mathrm{A}}, Z_{\mathrm{A}}\right)$ ke bidang proyeksi melalui suatu titik pusat proyeksi $\left(X_{0}, Y_{0}, Z_{0}\right)$, sehingga terbentuk posisi objek pada sistem koordinat foto $\left(x_{\mathrm{a}}, y_{\mathrm{a}}\right)$ seperti yang ditunjukkan pada Gambar 2.5.

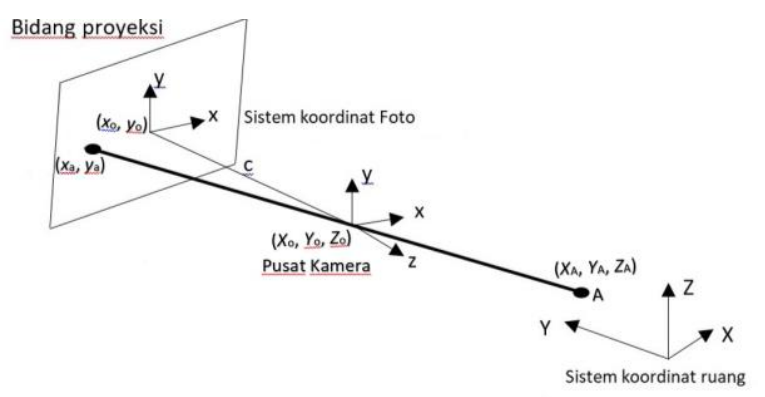

Gambar 2.5 Kondisi kolinieritas (Sumber: Atkinson, 1996)

Dalam Fotogrametri, posisi dari sebuah objek pada ruang didefinisikan pada sistem koordinat kartesian 3D. Pada awalnya, objek terdefinisi pada sistem koordinat berkas/foto, kemudian dilakukan transformasi koordinat untuk mendapatkan koordinat objek pada sistem koordinat tanah. Kedua sistem koordinat itu terdapat perbedaan orientasi dan skala, sehingga transformasi koordinat terdiri atas translasi, rotasi, dan perubahan skala.

Kalibrasi kamera dapat dilakukan dengan proses estimasi tidak langsung, dimana parameter orientasi dalam (IOP) dipulihkan. IOP kamera digital yaitu panjang fokus, koordinat principal point, dan koefisien kesalahan sistematis lensa (distorsi lensa radial, decentering, dan affinity). Secara umum, kalibrasi diselesaikan dengan persamaan kolinieritas untuk menentukan parameter koreksi lensa dan kamera (Atkinson, 1996; Wolf et al., 2014), yang disajikan dalam persamaan (1).

$$
\begin{aligned}
& x_{a}=x_{0}-c \frac{\left[m_{11}\left(X_{A}-X_{O}\right)+m_{12}\left(Y_{A}-Y_{O}\right)+m_{13}\left(Z_{A}-Z_{O}\right)\right]}{\left[m_{31}\left(X_{A}-X_{O}\right)+m_{32}\left(Y_{A}-Y_{O}\right)+m_{33}\left(Z_{A}-Z_{O}\right)\right]} \\
& y_{a}=y_{0}-c \frac{\left[m_{21}\left(X_{A}-X_{O}\right)+m_{22}\left(Y_{A}-Y_{O}\right)+m_{23}\left(Z_{A}-Z_{O}\right)\right]}{\left[m_{31}\left(X_{A}-X_{O}\right)+m_{32}\left(Y_{A}-Y_{O}\right)+m_{33}\left(Z_{A}-Z_{O}\right)\right]}
\end{aligned}
$$

\section{Keterangan :}

c : : principle distance

$\left(x_{0}, y_{0}\right) \quad$ : koordinat Principal Point (PP)

$\left(X_{\mathrm{A}}, Y_{\mathrm{A}}, Z_{\mathrm{A}}\right)$ : titik koordinat objek A

$\left(X_{0}, Y_{0}, Z_{0}\right)$ : titik koordinat pusat kamera

$\left(x_{\mathrm{a}}, y_{\mathrm{a}}\right) \quad$ : titik koordinat bidang foto

m : sudut rotasi omega (囵), phi (囵), kappa (?)

Pada persamaan (2), fungsi dari sudut rotasi omega (??), phi (?), kappa (?) merupakan elemen dari matriks rotasi.

$$
\begin{aligned}
& m_{11}=\cos \varphi \cos \kappa \\
& m_{12}=-\cos \varphi \sin \kappa \\
& m_{13}=\sin \varphi \\
& m_{21}=\sin \omega \sin \varphi \cos \kappa+\cos \omega \sin \kappa \\
& m_{22}=-\sin \omega \sin \varphi \sin \kappa+\cos \omega \cos \kappa \\
& m_{23}=-\sin \omega \cos \varphi \\
& m_{31}=-\cos \omega \sin \varphi \cos \kappa+\sin \omega \sin \kappa \\
& m_{32}=\cos \omega \sin \varphi \sin \kappa+\sin \omega \cos \kappa \\
& m_{33}=\cos \omega \cos \varphi
\end{aligned}
$$

$$
m=\left[\begin{array}{lll}
m_{11} & m_{12} & m_{13} \\
m_{21} & m_{22} & m_{23} \\
m_{31} & m_{32} & m_{33}
\end{array}\right]
$$

$\mathrm{m}_{\kappa}$ merupakan rotasi terhadap sumbu $\mathrm{z}, \mathrm{m}_{\omega}$ adalah rotasi terhadap sumbu $y$, sedangkan $\mathrm{m}_{\varphi}$ rotasi terhadap sumbu x.

Pada persamaan (3), ditampilkan persamaan kesalahan sistematis lensa.

$$
\begin{aligned}
& \Delta x=x\left(K_{1} r^{2}+K_{2} r^{4}+K_{3} r^{6}\right)+P_{1}\left(r^{2}+2 x^{2}\right)+2 P_{2} x y+A x+B y \\
& \Delta y=y\left(K_{1} r^{2}+K_{2} r^{4}+K_{3} r^{6}\right)+P 2\left(r^{2}+2 y^{2}\right)+2 P_{1} x y+A y
\end{aligned}
$$

\section{Keterangan :}

$\mathrm{K}_{1}, \mathrm{~K}_{2}, \mathrm{~K}_{3}$

$\mathrm{P}_{1}$ dan $\mathrm{P}_{2}$

A dan B

: koefesien sistematis distorsi radial
: koefesien distorsi decentering
: parameter affinity

Distorsi radial merupakan pergeseran linier titik foto dalam arah radial terhadap titik utama dari posisi idealnya. Distorsi tangensial atau distorsi decentric adalah pergeseran linier titik di foto pada arah normal (tegak 
lurus) garis radial melalui titik foto tersebut. Distorsi tangensial disebabkan kesalahan sentering elemen-elemen lensa dalam satu gabungan lensa dimana titik pusat elemen-elemen lensa dalam gabungan lensa tersebut tidak terletak pada satu garis lurus (Hanifa, 2007). Pada Gambar 2.6, dapat dilihat ilustrasi akibat adanya distorsi lensa dan tidak ortogonalnya sumbu atau affine deformation.

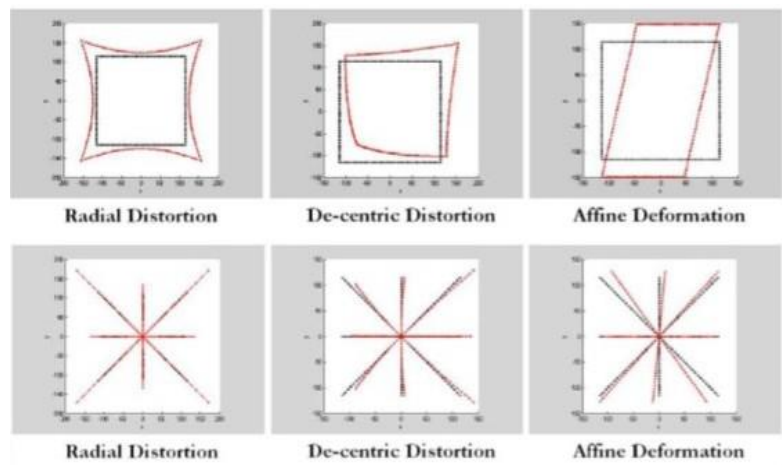

Gambar 2.6 Distorsi lensa (Sumber: Pullivelli, 2005)

\subsection{Hasil dan Analisis}

Jenis data yang dihasilkan adalah nilai IOP kamera dan standar deviasinya, analisis kesalahan scale bars, dan model 3D objek. Hasil dari kalibrasi kamera merupakan salah satu hasil yang penting dalam pemodelan $3 \mathrm{D}$. Kalibrasi kamera merupakan suatu proses yang berpengaruh terhadap parameter internal dari kamera yang dibutuhkan untuk merekonstruksi ulang berkas sinar pada saat pemotretan (Ananingtyas et al., 2016). Oleh karena itu proses kalibrasi sangat dibutuhkan dalam pemodelan 3D.

\section{Hasil dan Pembahasan}

\subsection{Interior Orientation Parameter (IOP)}

Hasil kalibrasi kamera dengan menggunakan bundle adjustment pada perangkat lunak Agisoft Photoscan Profesional menghasilkan parameter IOP (Interior Orientation Parameter) yaitu nilai principal distance (C), principal point $\left(\mathrm{x}_{0}, \mathrm{y}_{0}\right)$, dan parameter distorsi lensa $\left(\mathrm{K}_{1}, \mathrm{~K}_{2}\right.$, $\left.\mathrm{K}_{3}, \mathrm{P}_{1}, \mathrm{P}_{2}, \mathrm{~B}_{1}, \mathrm{~B}_{2}\right)$.

Pada Tabel 3.1, dapat dilihat nilai parameter IOP dan standar deviasinya. Standar deviasi dapat didefinisikan sebagai nilai kemungkinan kuadrat sekitar nilai rata-rata untuk variabel acak dan akar kuadrat positif menjadi standar deviasi (Hanifa, 2007; Hassan et al., 2014). Pada persamaan (4), ditampilkan rumus standar deviasi.

$$
\sigma=\frac{\sum(x-\bar{x})^{2}}{(n-1)}
$$

\section{Keterangan :}

$\begin{array}{ll}\sigma & : \text { standar deviasi } \\ x & \text { : nilai masing-masing data } \\ \bar{x} & : \text { mean dari seluruh data } \\ n & : \text { jumlah data }\end{array}$

Tabel 3.1 Nilai IOP dan standar deviasinya

\begin{tabular}{ccc}
\hline $\begin{array}{c}\text { Camera } \\
\text { Variable }\end{array}$ & $\begin{array}{c}\text { Nilai } \\
\text { Parameter }\end{array}$ & Standar Deviasi \\
\hline $\mathrm{C}$ & $1,3901(\mathrm{~mm})$ & $0,0036(\mathrm{~mm})$ \\
$\mathrm{x}_{0}$ & $0,0049(\mathrm{~mm})$ & $0,0000(\mathrm{~mm})$ \\
$\mathrm{y}_{0}$ & $-0,0000(\mathrm{~mm})$ & $0,0000(\mathrm{~mm})$ \\
$\mathrm{K}_{1}$ & $1,267 \times 10^{-1}$ & $8,286 \times 10^{-4}$ \\
$\mathrm{~K}_{2}$ & $5,749 \times 10^{-3}$ & $6,291 \times 10^{-5}$ \\
$\mathrm{~K}_{3}$ & $4,557 \times 10^{-3}$ & $1,932 \times 10^{-5}$ \\
$\mathrm{P}_{1}$ & $1,051 \times 10^{-2}$ & $1,069 \times 10^{-4}$ \\
$\mathrm{P}_{2}$ & $-8,196 \times 10^{-5}$ & $1,066 \times 10^{-4}$ \\
$\mathrm{~B}_{1}$ & $-7,104 \times 10^{-2}$ & $1,138 \times 10^{-3}$ \\
$\mathrm{~B}_{2}$ & $-6,129 \times 10^{-6}$ & $4,849 \times 10^{-6}$ \\
\hline
\end{tabular}

Hasil koefesien kalibrasi dan matriks korelasi ditampilkan pada Tabel 3.2.

Tabel 3.2 Calibration coefficients dan correlation matrix

\begin{tabular}{cccccccc}
\hline & Nilai & Error & $\mathbf{F}$ & $\mathbf{B}_{\mathbf{1}}$ & $\mathbf{K}_{\mathbf{1}}$ & $\mathbf{P}_{\mathbf{1}}$ & $\mathbf{P}_{\mathbf{2}}$ \\
\hline $\mathbf{F}$ & 1913,88 & 5 & 1,00 & $-0,40$ & $-0,81$ & 0,36 & $-0,13$ \\
$\mathbf{B}_{\mathbf{1}}$ & 109,365 & 2,3 & & 1,00 & $-0,09$ & 0,05 & 0,02 \\
$\mathbf{K}_{\mathbf{1}}$ & 0,0805595 & 0,0011 & & & 1,00 & $-0,51$ & 0,16 \\
$\mathbf{P}_{\mathbf{1}}$ & $-0,00787374$ & 0,0002 & & & & 1,00 & $-0,02$ \\
$\mathbf{P}_{\mathbf{2}}$ & $-6,329 \times 10^{-5}$ & 0,00017 & & & & & 1,00 \\
\hline
\end{tabular}

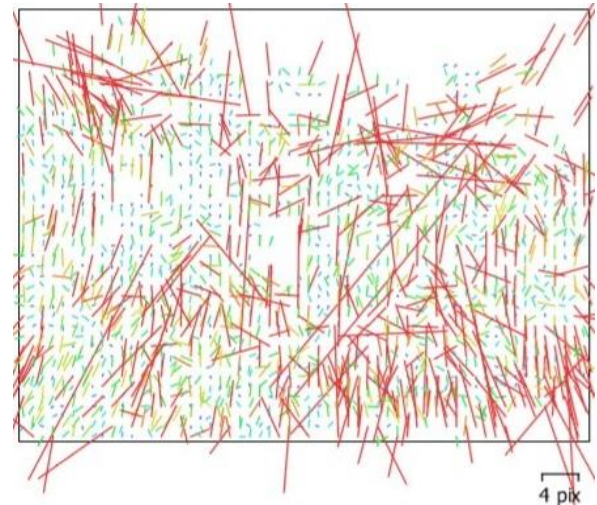

Gambar 3.1 Image residuals $(2,73 \mathrm{~mm})$
Pada Gambar 3.1, menampilkan sisa efek residu foto yang masih ada, dengan distorsi yang menyebar dan tidak konsisten. Distorsi lensa dapat menyebabkan bergesernya titik pada foto dari posisi yang sebenarnya, sehingga memberikan ketelitian pengukuran yang tidak baik, namun tidak mempengaruhi kualitas ketajaman foto yang dihasilkan.

\subsection{Analisis Kesalahan Scale Bar}

Scale bar pada software Agisoft Photoscan Professional dapat merepresentasikan jarak yang diketahui dalam scene. Ini bisa menjadi penggaris standar atau bar yang disiapkan khusus dengan panjang yang diketahui. Mereka dapat terbukti berguna ketika tidak ada cara untuk menemukan titik kontrol tanah di seluruh tempat kejadian. Pada Tabel 3.3, dapat dilihat nilai kontrol scale bar, antara pengukuran jarak di lapangan dan perhitungan jarak pada 
software Agisoft Photoscan Professional dengan akurasi $0.001 \mathrm{~m}$.

Tabel 3.3 Control scale bar

\begin{tabular}{cccc}
\hline $\begin{array}{c}\text { Label Coded } \\
\text { Targets }\end{array}$ & $\begin{array}{c}\text { Ukuran Jarak } \\
\text { di lapangan } \\
\text { (m) }\end{array}$ & $\begin{array}{c}\text { Ukuran Jarak } \\
\text { di software } \\
\text { (m) }\end{array}$ & Error (m) \\
\hline Target 17 - Target 19 & 1,082 & 1,06227 & $-0,0197336$ \\
Target 17 - Target 18 & 0,924 & 0,933029 & 0,00902865 \\
Target 18 - Target 19 & 0,661 & 0,665417 & 0,0044174 \\
Target 15 - Target 19 & 2,520 & 2,49514 & $-0,0248572$ \\
Target 15 - Target 18 & 2,205 & 2,19826 & $-0,0067401$ \\
Target 15 - Target 17 & 1,441 & 1,4371 & $-0,0039039$ \\
Target 17 - Target 34 & 2,676 & 2,69734 & 0,021339 \\
Target 15 - Target 34 & 1,247 & 1,27425 & 0,027247 \\
\hline Total & & & 0,0172001 \\
\hline
\end{tabular}

Agisoft Photoscan Professional mendukung pengukuran jarak pada model, serta luas permukaan dan volume model 3D yang direkonstruksi. Semua instruksi dari bagian ini berlaku untuk bekerja pada model view dari program, baik untuk analisis Dense Point Cloud atau data Mesh. Saat bekerja dalam model view, semua pengukuran dilakukan dalam ruang 3D, tidak seperti pengukuran dalam tampilan Ortho, yang merupakan gambar planar.

\subsection{Model 3D Objek}

Pengolahan foto dan kalibrasi kamera menghasilkan pemodelan 3D objek fasad bangunan rumah bagian dalam. Analisa bentuk 3D Model objek hasil kalibrasi otomatis pada pengolahan foto masih terdapat kekurangan. Model 3D objek bagian dalam fasad bangunan rumah dapat ditampilkan pada Gambar 3.2.

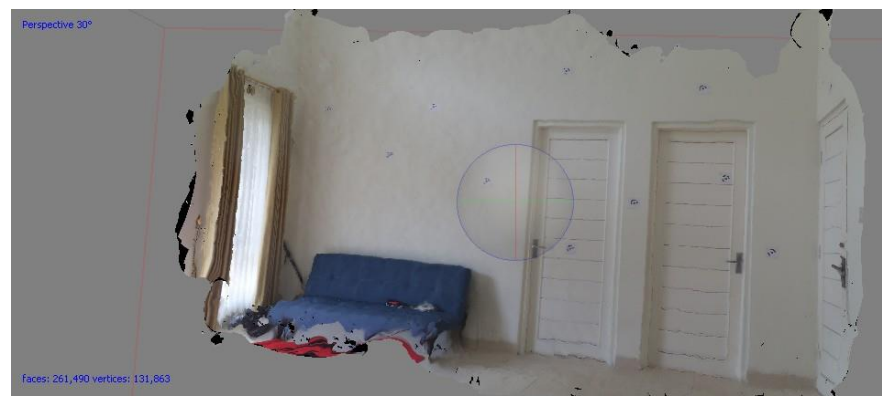

Gambar 3.2 Model 3D Objek

\section{Kesimpulan}

Berdasarkan hasil yang diperoleh maka dapat disimpulkan bahwa Maximum Observational Radial Distance Encountered sebesar $1 \mathrm{~mm}$. Setelah pemrosesan dengan software Agisoft Photoscan Professional, nilai parameter kamera stabil dan memiliki akurasi tinggi, akurasi kalibrasi elemen orientasi dalam adalah dalam mikron. Parameter kalibrasi kamera sering kali berubah tidak teratur. Total kontrol kesalahan pengukuran jarak langsung dan perhitungan jarak software pada pasangan coded targets adalah sebesar 0,0172 m. Model 3D yang dihasilkan bisa dikatakan bagus untuk objek yang memiliki tekstur homogen.

\section{Pernyataan Konflik Kepentingan}

Penulis menyatakan tidak ada konflik kepentingan dalam artikel ini (The authors declare no competing interest).

\section{Referensi}

Agisoft, P. (2017). Manual Agisoft Photoscan Professional.

Ananingtyas, F., Prasetyo, Y., \& Suprayogi, A. (2016). Aplikasi Fotogrametri Jarak Dekat untuk Pemodelan 3D Wajah Manusia. Jurnal Geodesi Undip, 5(April), 179-189.

Atkinson, K. B. (1996). Close Range Photogrammetry and Machine Vision. Scotland UK: Whittles Publisher.

Clarke, T., \& Fryer, J. (1998). The Development of Camera Calibration Methods and Models. Photogrammetric Record, 16(91), 51-66.

Cox, B. C. (2016). Mobile Mapping Systems A Buyer's Guide. (March).

Hanifa, N. R. (2007). Studi Penggunaan Kamera Digital Low-Cost Non-Metric Auto-Focus untuk Pemantauan Deformasi. Institut Teknologi Bandung.

Hassan, M. F. A., Ma'Arof, I., \& Samad, A. M. (2014). Assessment of Camera Calibration Towards Accuracy Requirement. Proceedings - 2014 IEEE 10th International Colloquium on Signal Processing and Its Applications, CSPA 2014, 123-128. https://doi.org/10.1109/CSPA.2014.6805733

Kraus, K. (1997). Photogrammetry: Advanced Methods and Applications. Bonn: Ferd Dümmlers Verlag, Volume 2.

Luhmann, T., Robson, S., Kyle, S., \& Harley, S. (2006). Close Range Photogrammetry: Principles, Techniques and Applications. Caithness: Whittles Publishing.

McGlone, J., Mikhail, E., Bethel, J., \& Mullen, R. (2004). Manual of Photogrammetry. Maryland: American Society for Photogrammetry and Remote Sensing.

Pullivelli, A. (2005). Low-Cost Digital Cameras : Calibration, Stability Analysis, and Applications. University of Calgary.

Remondino, F., \& Fraser, C. (2006). Digital Camera Calibration Methods: Considerations and Comparisons. The International Archives of the Photogrammetry, Remote Sensing and Spatial Information Sciences, 36(5), 266-272.

Tang, R. (2013). Mathematical Methods for Camera SelfCalibration in Photogrammetry and Computer Vision. University of Stuttgart, Munchen.

Teo, T. (2015). Video-Based Point Cloud Generation Using Multiple Action Cameras. International Archives of the Photogrammetry, Remote Sensing and Spatial Information Sciences-ISPRS Archives, 40(4W5), 5560. https://doi.org/10.5194/isprsarchives-XL-4-W5$55-2015$

Wolf, P. R., Dewitt, B. A., \& Wilkinson, B. E. (2014). Elements of Photogrammetry with Applications in GIS (4 ed.). United States: Mc Graw-Hill Education. 